\title{
Granular cell tumour of the common bile duct
}

\author{
Sarah Cheslyn-Curtis*, R.C.G. Russell, J. Rode and A.P. Dhillon $\dagger$
}

The Middlesex Hospital, London WIN 1AA, UK.

\begin{abstract}
Summary: Granular cell tumours are a rare cause of benign biliary stricture. A case is reported which is unusual in that the diagnosis was made before the onset of jaundice. We emphasize the importance of accurate histology of biliary strictures, to eliminate confusion between those of benign and malignant nature and to ensure that the appropriate management is undertaken. Immunohistochemical evidence for the neural origin of this rare tumour is presented.
\end{abstract}

\section{Introduction}

Granular cell tumours (GCT) are uncommon benign lesions whose histogenesis has remained obscure since their description by Abrikossoff in 1926. Their occurrence in the extrahepatic biliary tree is rare and of the 33 cases so far described, only 3 have been reported in the British literature (Savage \& Devitt, 1977; Dewar et al., 1981; Barber, 1984). A granular cell tumour of the common bile duct is described which is unusual in that the diagnosis was made before the onset of jaundice.

\section{Case report}

A 38 year old Caucasian woman presented with a one year history of recurrent attacks of colicky, right hypochondrial pain each lasting several hours. There was no history of jaundice and examination was unremarkable.

An oral cholecystogram failed to opacify the gall bladder but ultrasound examination of the gall bladder was normal. Liver function tests performed shortly after an attack of pain showed: alkaline phosphatase $345 \mathrm{IU} / 1$ (normal 30-110 IU/l), aspartate transaminase $99 \mathrm{IU} / 1$ (normal 5-40 IU/l) and bilirubin $15 \mu \mathrm{mol} / 1$ (normal 5-17 $\mu \mathrm{mol} / 1$ ). In the absence of gallstones and with abnormal liver function tests bile duct obstruction was suspected. Endoscopic retrograde cholangiopancreatography (ERCP) showed a tight stricture in the mid-portion of the bile duct, absent filling of the

*Correspondence and present address: S. Cheslyn-Curtis, F.R.C.S., Academic Surgical Unit, St Mary's Hospital, London W2, UK.

†Present address: Department of Histopathology, Royal Free Hospital, London NW3, UK.

Accepted: 12 May 1986 cystic duct and dilatation of the biliary tree above the stricture (Figure 1).

A malignant bile duct stricture was suspected and at laparotomy a $1 \mathrm{~cm}$ firm nodule was found in the

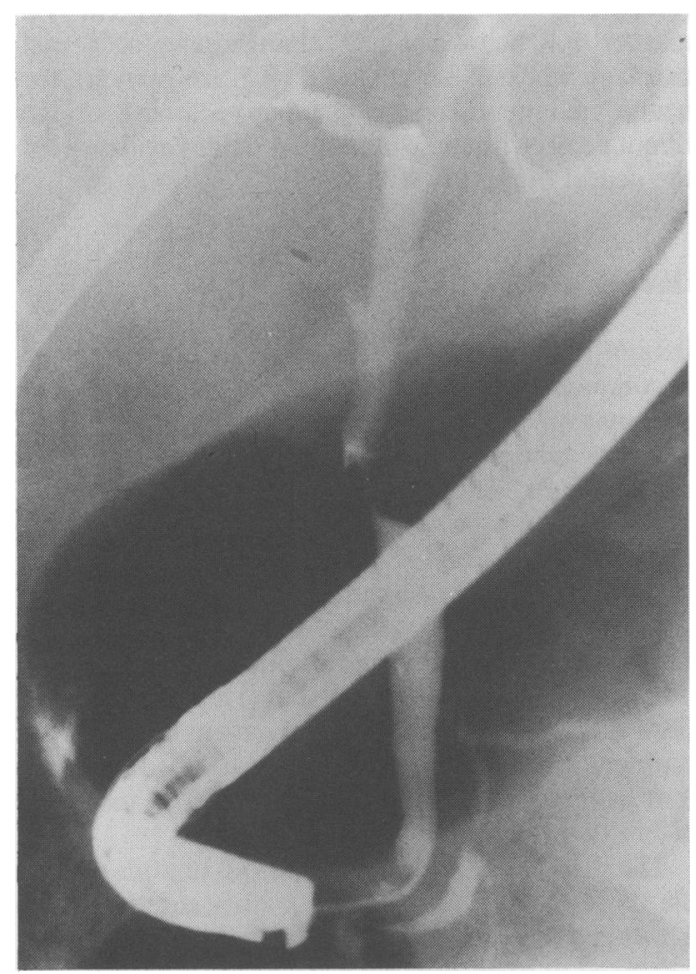

Figure 1 ERCP showing a tight stricture in the midportion of the bile duct, absent filling of the cystic duct and dilatation of the biliary tree above the stricture.

(C) The Fellowship of Postgraduate Medicine, 1986 
common bile duct at its junction with the cystic and common hepatic ducts. The common hepatic duct was dilated and the gall bladder collapsed. The nodule was resected with a cuff of normal bile duct, cystic duct and gall bladder and a Roux-en-Y hepato-jejunostomy performed. The patient made an uncomplicated recovery and remains well 2 years later.

\section{Pathology}

A firm nodule measuring $1 \mathrm{~cm}$ in diameter with a yellow-white cut surface was noted within the wall of the common bile duct almost occluding its lumen and completely obstructing the cystic duct. The gall bladder was normal and did not contain stones. Histologically, the lesion did not appear encapsulated and was composed of clumps of large cells with distinct cell boundaries, small dark round nuclei and eosinophilic granular cytoplasm. These are the features of a granular cell tumour.

In some areas the tumour cells were closely associated with nerve bundles of an unusually large size for the biliary tree. The tumour cells showed staining for S-100 protein, neurone-specific enolase (NSE) (Figure 2) and PGP 9.5. S-100 protein is a marker for Schwann cells, Langerhans cells and cartilage whilst NSE and PGP 9.5 are markers for neural and neuroendocrine tissue. Staining of the tumour cells with these markers provides evidence for the neural origin of GCT.

\section{Discussion}

Benign tumours of the extrahepatic biliary tree are uncommon and are usually epithelial (papillomas and adenomas) or predominantly epithelial (adenomyomas and polyps). Granular cell tumours at this site are rare. There have been 33 cases reported including 16 in the common bile duct (Figure 3). A review of these cases shows that GCT of the extrahepatic biliary tree occurs almost exclusively in women $(94 \%)$ and usually presents in the third to fifth decades. It appears to be more common in negroes as is true of GCT found at other sites (Lack et al., 1980). GCT is occasionally multiple: one patient had multiple tumours in the biliary tree (Aisner et al., 1982) and four had tumours elsewhere (Assor, 1979; Manstein et al., 1981; Livolsi et al., 1973).

The clinical features of granular cell tumour resemble those of both malignant bile duct strictures and gallstones. The benign nature of this tumour may be suspected at operation but confirmation of the diagnosis depends on histological examination of the resected specimen. Except for two tumours found at post-mortem (Coggins, 1952; Whitmore et al., 1969)

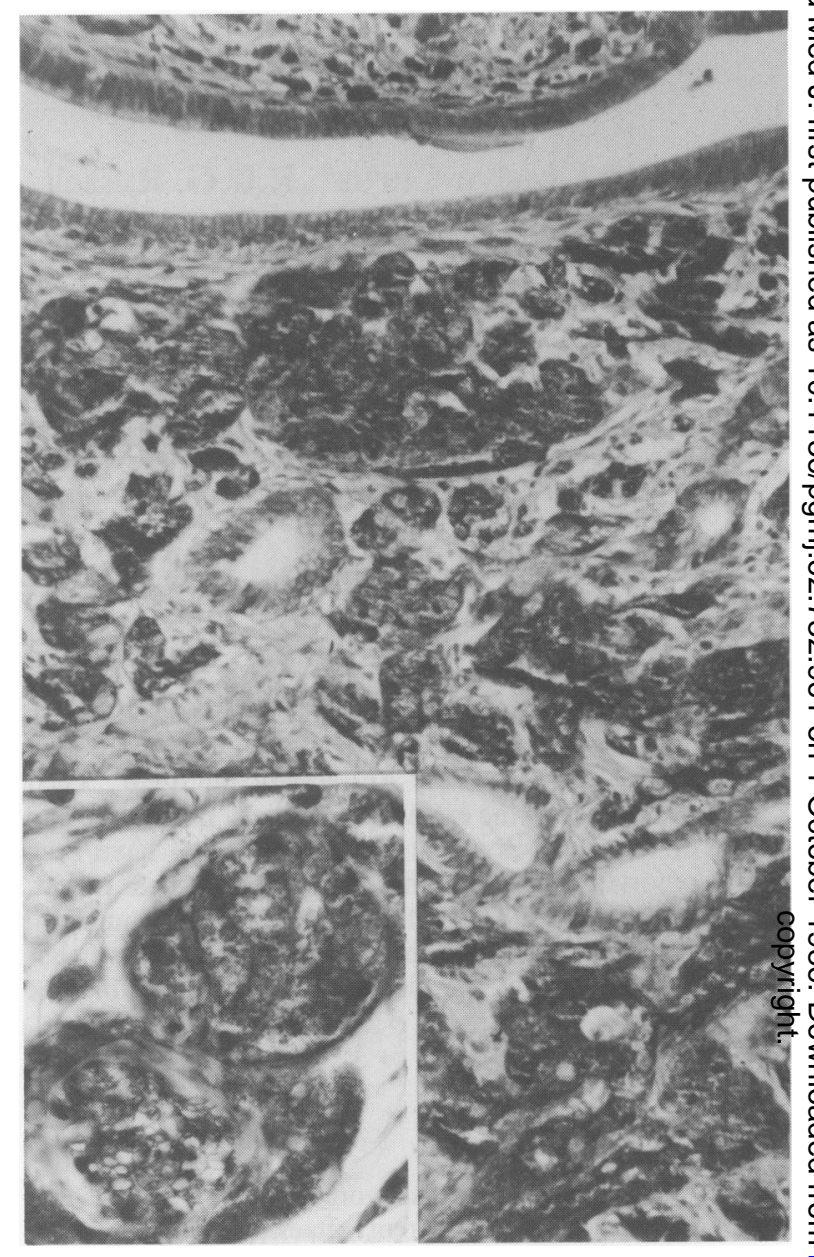

Figure 2 Granular cell tumour of the wall of the common bile duct immunostained for neurone-specific enolase. Tumour cells with abundant granular cytoplasm are seen staining darkly beneath the surface epithelium (upper part) and around glands of the bile duct $-\times 110$. Inset: High power view of neurone-specific enolase positive tumour cells within and around the perineurium of a small nerve, $\times 230$.

all previously reported lesions have been successfully treated surgically.

GCT is much more common at sites outside the biliary tree and has been described in most parts of the body. The commonest sites are the skin, subcutaneous tissues, oral cavity and tongue (Lack et al., 1980). At certain sites such as the biliary tract, bronchus (Garancis et al., 1970), vocal cord or oesophagus (Mauro \& Jacques, 1981) GCT can produce significant symptoms and may be mistaken for a malignant lesion. 


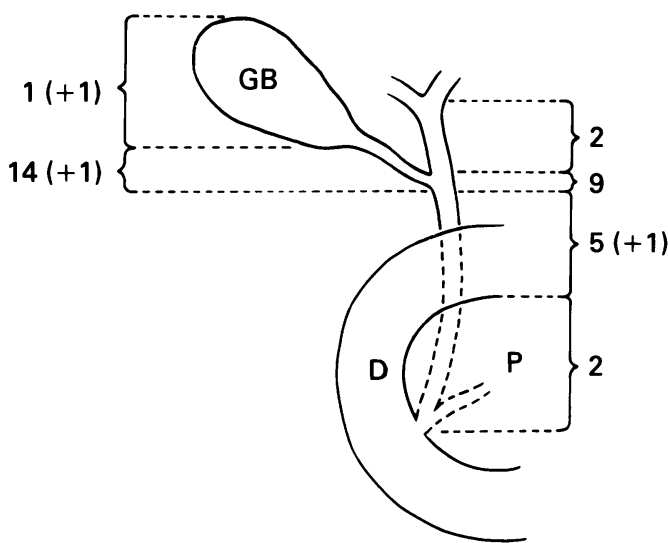

Figure 3 Distribution of GCT in the extrahepatic biliary tree. $\mathbf{G B}=$ gall bladder, $\mathrm{D}=$ duodenum, $\mathbf{P}=$ pancreas, ()$=$ multiple tumours in one patient.

The histogenesis of GCT is unclear, a neural origin being the most widely accepted view at present. These tumours are often closely associated with nerves and occasionally wholly confined within a nerve (Bangle,

\section{References}

ABRIKOSSOFF, A. (1926). Über Myome, ausgehend von der quergestreiften willkürlichen Muskulatur. Virchows Archiv für Pathologische Anatomie, 260, 215.

AISNER, S.C., KHANEHA, S. \& RAMIREZ, O. (1982). Multiple granular cell tumours of the gall bladder and biliary tree. Report of a case. Archives of Pathology and Laboratory Medicine, 106, 470.

ASSOR, D. (1979). Granular cell myoblastoma involving the common bile duct. American Journal of Surgery, 137, 673.

BARBER, C.J. (1984). Granular cell tumour of the cystic duct. A cause of cholecystitis. Journal of the Royal College of Surgeons of Edinburgh, 29, 56.

BANGLE, R. (1953). An early granular cell myoblastoma confined within a small peripheral myelinated nerve. Cancer, 6, 791.

COGGINS, R.P. (1952). Granular cell myoblastoma of the common bile duct. Archives of Pathology, 54, 398.

DEWAR, J., DOOLEY, J.S., LINDSAY, I., GEORGE, P. \& SHERLOCK, S. (1981). Granular cell myoblastoma of the common bile duct treated by biliary drainage and surgery. Gut, 22, 70.

DHILLON, A.P. \& RODE, J. (1983). Immunohistochemical studies of S100 protein and other neural characteristics expressed by granular cell tumour. Diagnostic Histopathology, 6, 23.

FISHER, E.R. \& WECHSLER, H. (1962). Granular cell myoblastoma - a misnomer. Electron microscopic and histochemical evidence concerning its Schwann cell derivation and nature (granular cell Schwannomas). Cancer, 15, 936.
1953). GCT cells contain granules resembling the secretory granules characteristic of neural cells and show immunohistochemical staining for the Schwann cell marker S-100 protein (Dhillon \& Rode, 1983) and the neural markers PGP 9.5 and NSE (Rode et al., 1982, 1985). A Schwann cell origin has been proposed (Fischer \& Wechsler, 1962) but more recently Rode et al. (1982) suggested that this tumour arises from an undifferentiated precursor cell which has the capacity to differentiate into either Schwann or GCT cells.

Granular cell tumour is a rare, benign lesion which may cause bile duct obstruction and should be considered in the differential diagnosis of biliary pain with or without jaundice. Accurate histology of biliary strictures is important to eliminate confusion between those of benign and malignant nature and to ensure that the appropriate management is undertaken.

\section{Acknowledgements}

We are grateful to Dr P.B. Cotton for permission to report the ERCP.

GARANCIS, J.C., KOMOROWSKI, R.A. \& KUZMA, J.F. (1970). Granular cell myoblastoma. Cancer, 25, 542.

LACK, E.E., WORSHAM, G.F., CALLIHAN, M.D., CRAWFORD, B.E., KLAPPENBACH, S., ROWDEN, G. \& CHUN, B. (1980). Granular cell tumour: A clinicopathological study of 110 patients. Journal of Surgical Oncology, 13, 301.

LIVOLSI, V.A., PERZIN, K.H., PRICE, J.B. \& PORTER, M. (1973). Granular cell tumors of the biliary tract. Archives of Pathology, 95, 13.

MANSTEIN, M.A., MCBREARTY, F.X., PELLECHIA, P.E. \& PASKIN, D.L. (1981). Granular cell tumour of the common bile duct. Digestive Diseases Science, 26, 938.

MAURO, M.A. \& JACQUES, P.F. (1981). Granular cell tumors of the oesophagus and common bile duct. Journal of the Canadian Association of Radiologists, 32, 254.

RODE, J., DHILLON, A.P., DORAN, J.F., JACKSON, P. \& THOMPSON, R.J. (1985). PGP 9.5, a new marker for human neuroendocrine tumours. Histopathology, 9, 147.

RODE, J., DHILLON, A.P. \& PAPADAKI, L. (1982). Immunohistochemical staining of granular cell tumour for neurone specific enolase: Evidence in support of a neural origin. Diagnostic Histopathology, 5, 205.

SAVAGE, A. \& DEVITT, P. (1977). Granular cell myoblastoma of the biliary tree. Postgraduate Medical Journal, 53, 574.

WHITMORE, J.T., WHITLEY, J.P., LAVERDE, P. \& CERDA, J.J. (1969). Granular cell myoblastoma of the common bile duct. American Journal of Digestive Diseases, 14, 516. 